\title{
Classroom Leadership and Creativity: A Study of Social Studies and Islamic Education Teachers in Jordan
}

\author{
Samih Al-Karasneh ${ }^{1}$, Ali Jubran ${ }^{2}$ \\ ${ }^{1}$ Faculty of Education, Yarmouk University, Irbid, Jordan \\ ${ }^{2}$ Department of Administration and Foundations of Education, Faculty of Education, \\ Yarmouk University, Irbid, Jordan \\ Email: nhsamih@yahoo.com
}

Received December 20 $0^{\text {th }}$, 2012; revised January $18^{\text {th }}$, 2013; accepted January $25^{\text {th }}, 2013$

\begin{abstract}
Copyright (c) 2013 Samih Al-Karasneh, Ali Jubran. This is an open access article distributed under the Creative Commons Attribution License, which permits unrestricted use, distribution, and reproduction in any medium, provided the original work is properly cited.
\end{abstract}

\begin{abstract}
The purpose of this study was to investigate the leadership practices and creativity traits as perceived by social studies and Islamic education teachers in Jordan. A sample of 289 social studies and Islamic education teachers were selected randomly. Data were collected using quantitative research method. Leadership practices were measured using the Leadership Practices Inventory (LPI-Self) developed by Kouzes and Posner (2003) with self-developed items on the Islamic component by the researchers, and creativity traits were measured using the Creativity Self-Perception Questionnaire (CSPQ) developed by Goertz (1993). The validity and the reliability of two instruments are already developed and assessed. The data have been statistically analyzed (by using the SPSS). Findings of the study revealed that teachers perceived themselves positively in all dimensions studied. They were also found to be creative, as they perceived themselves to possess all the creativity traits. The study also showed that there was a significant correlation between the results of the ten leadership dimensions together and the eight creativity traits of teachers were positively significant. The results showed that there were no significant differences according to the dependent variables (gender, major of specialization, educational experience, and stage of schools) on most of the independent variables (eight creativity traits and ten leadership dimensions). The study also offered some recommendations to enhance the status of educational leadership, creativity of social studies and Islamic education teachers.
\end{abstract}

Keywords: Classroom; Leadership; Creativity; Social Studies; Islamic Education

\section{Introduction}

Classroom environment has been seen as a very complex setting with multiple dimensions (Jackson, 1968; Doyle, 1977). It has been shaped by continual experience and an accumulation of daily classroom activities (Doyle, 1977, 1981, 1983, 1986; Desforges \& Cockburn, 1987; Desforges, 1995; Desforges, 2000). In the classroom, teachers must make many decisions simultaneously. They have to plan suitable activities for different purposes, needs and nature of individual students, ask them questions, listen to their answers, answer their questions, comment on their answers, motivate them, correct them if they make a mistake, and provide feedback. For Jackson (1968), the reality of this environment makes teachers' work potentially very complicated. Beswick (2008), however, asserts that this complexity of the classroom could provide teachers with opportunities to think about structuring their classroom environment and teaching to maximize the chances of creativity emerging. Thus, the effective management of a classroom environment can contribute to the development of creative potential.

In reference to Slahova, Savvina, Cacka and Volonte (2007), the development of creative activity is a very complicated process that takes place over a whole period of classroom life and depends on social, material and mental factors. Accordingly, the foundation of creativity in the classroom depends on the teacher's thought and interaction with the students, ranging from teacher's rapport with the students to the approach of instructing, assessing, and tackling the complexity of the classroom.

According to Sternberg and Williams (1996), a learning environment that fosters creativity should include several components, namely: allowing time for creative thinking; rewarding creative ideas and products; encouraging sensible risks; allowing mistakes; imagining other viewpoints; exploring the environment; questioning assumptions finding interests and problems; generating multiple hypotheses; focusing on broad ideas rather than specific facts; and thinking about the thinking processes (Starko, 1995). Therefore, to foster creativity, social studies (SS) and Islamic education (IE) teachers should be aware of these components.

With respect to education in specific, creativity is an essential element for learning. Starko (1995) suggests that learning is a creative process that involves students making use of relevant information by linking prior knowledge and new knowledge in an individually meaningful context. Studies in creativity have tried to conceptualize the term creativity and explain the process involved in the creative act. Although there is no consensus about how to define creativity, most definitions emphasize the role of the environment in promoting or inhibiting creative 
abilities. Csikszentmihalyi (1988) suggests that the most fundamental question in creativity is "where is creativity" and not "what is creativity". He highlights that the educational environment plays an important role in developing students' creative expression. In the present study, however, creativity is used as defined by Plucker and Beghetto as follows:

"Creativity is the interplay between ability and process by which an individual or group produces an outcome or product that is both novel and useful as defined within some social context" (2004: p. 156).

Related research stresses the centrality of the role of teachers where teachers' understanding is considered to be imperative in producing a creative classroom environment (Anderman \& Midgley, 1998). In creating this type of environment, it is recommended that social studies and Islamic education teachers should acknowledge and encourage creative thinking, tolerate dissent, encourage students to trust their own judgments, emphasize that everyone is capable of creativity, and serve as a stimulus for creative thinking through brainstorming and modeling, Social studies and Islamic education teachers are expected to be the front-runners of classroom creativity. They have a huge influence on their students as they lead and manage them. Morganett (1991) stated that quality teacher-student interactions can encourage students to be active learners in the classroom, which will foster creativity.

As a consequence, creativity in the classroom needs effective leadership (Wildy \& Louden, 2002). Leadership consists of actions that help teachers to complete learning tasks successfully and maintain effective working relationships with students and among them (Johnson, 1991). For Gunter (2001) the effectiveness of teachers' leadership contributes to the success of creativity in the classrooms. For Datnow and Castellano, (2001), the positive impact of teachers' leadership gained validation when researchers found that teacher leadership is the single most powerful determinant of classroom effectiveness. The role of effective classroom leadership, is therefore, a key to nurturing creativity and creative leaders are needed in the educational arena in order to improve classroom productivity (Blumberg \& Greenfield, 1986; Ubben \& Hughes, 1997). To emphasize the importance of creativity in classrooms, Johnson (1991) asserts that "the creative leader is seeking not to control but to free the creative potential of others and is not so much an optimist as a believer that this liberation is possible” (p. 29). As leaders, Social studies and Islamic education teachers have to be creative in teaching, in building a positive environment, and in managing different affairs that gear the classroom towards excellence. Therefore, they carry the responsibility of managing learning and creativity in the classroom (Lumsden, 1994; Hess \& Kelly, 2007). Consequently, Social studies and Islamic education teachers, as creative leaders, have to carry out several managerial and administrative roles and tasks. Beare, Coldwell, and Millikan (1989) and Lashway, Mazarella and Grundy (1996) believe that successful leadership must involve a mastery of managerial and administrative skills as well as certain personal qualities (Munitz, 1999). In other words, classroom leaders must first of all be skillful managers (Munitz, 1999; Dunford, Fawcett, \& Bennett, 2000).

However, managerial skills are essential for any classroom leaders to succeed and to be the front-runners of the classroom. Teachers as leaders have an enormous influence on their students as they lead and manage them. For teachers, having these skills will enable them to modify suggestions for the specific needs of their classroom. Moreover, teachers' managerial skills will define the kind and quality of leadership they have (Munitz, 1999).

\section{Related Literature}

The achievement of creativity in social studies and Islamic education classrooms is one of the main roles of teachers who are considered as the educational leaders and managers. Therefore, some general leadership and administration theories were studied in order to apply what is relevant to the educational situations and classroom environment. A relevant theory on leaders by Kouzes and Posner (2003) distinguishes leaders from managers and identifies what they consider as the most important five descriptive qualities of superior leaders. According to them, leaders must be honest, competent, forward-looking, inspiring and intelligent. They also present a leadership model that consists of five fundamental practices that are presumed to enable leaders to achieve extraordinary things. These practices are: challenging the process, inspiring a shared vision, enabling others to act, modeling the way and encouraging the heart.

Adopting the above theory, Schnook sought to investigate the perceptions of principals and teachers with regard to the demonstration of the leadership practices in schools in Florida, United States (Schmook, 1996). She concluded that principals of Florida schools clearly demonstrated the five leadership practices (Ibid.). In addition, studies that applied Kouzes and Posner' theory have also been conducted in many colleges, universities and secondary schools. There are more than 200 doctoral and Masters theses utilizing the theory such as $\mathrm{Xu}$, 1991; Aubrey, 1992; Nolan, 1992; Koster-Peterson, 1993; Weltman, 1995; Cavaliere, 1995; Muhammad, 1996; Morris, 1998; Oumthanom, 2001; Schmiesing, 2001; Taylor, 2002.

In the context of the Islamic and Arab world in specific, many scholars have discussed the theory of Kouzes and Posner too. In their book titled Leadership: An Islamic Perspective, Beekun and Badawi (1999) stated that Kouzes and Posner's theory is "one of the best models of effective leadership" (p. 115). They have adopted the five leadership practices. The authors emphasized that Muslim leaders need such practices in order to be effective and achieve the objectives of their organizations.

Goertz (1991), in her study on the relationship of leader effectiveness and selected traits of creativity, found that effective people in leadership positions demonstrate selected traits of creativity. She views creativity as "a special condition, attitude, or state of being that reflects passion for work, independence, goal setting, originality, flexibility, a wide range of interests, average or above-average intelligence and motivation” (1991).

In her study that focused on leadership and creativity, Schmook (1996) used Goertz's creativity traits of passion for work, independence, goal setting, originality, and flexibility, wide range of interests, intelligence and motivation in assessing selected Florida schools. The researcher sought to determine and investigate the perceptions of principals and teachers in regard to the demonstrated creativity traits of Goertz. It is interesting to note here that many educators and researchers considered creativity traits as important in any association. They emphasize the importance of such creativity in educational settings as a means of enhancing effectiveness and bringing success to the organization (Eisawi, 1990; Jarwan, 1990; AlMazeidy, 1993; Al-Hammadi, 1996; Al-Safi, 1997; Sweidan \& 
Adlouni, 2002; Al-Sorour, 2002).

Several researchers studied creativity in the classroom. For example, Darnell, Gallagher, Andrews and Amaral (2000) conducted a qualitative investigation of a supportive classroom environment for developing student creativity. Observations and interview data collected focused on assessment, classroom activities, and the teacher's effort in creating this supportive environment. Teacher-student relationships, de-emphasizing standardized assessment, and encouraging multiple perspectives was significant to this creative milieu. The study focused on the teacher's role in creating this creative environment.

Furthermore, Fleith (2000) investigated teachers and students perceptions about characteristics which either stimulate or inhibit the development of creativity in the classroom environment. Interviews were conducted with seven Connecticut public school teachers and 31 students (Grades 3 and 4). The findings suggest that both teachers and students believe that a classroom environment which enhances creativity provides students with choices, accepts different ideas, boosts self-confidence, and focuses on students' strengths and interests. On the other hand, in an environment which inhibits creativity, ideas are ignored, teachers are controlling, and excessive structure exists.

The above mentioned studies on leadership and creativity describe the significance of educational leadership in the success of classroom teaching and learning. The high quality learning outcomes can be achieved if there is proper and effective educational leadership. However, according to the related literature, very little research has been carried out about the concept of "classroom leadership and creativity". It has become clear that no research examined this area of research in the Arab world and in Jordan, per se. Also, investigating teachers' views of classroom leadership and creativity is supposed to offer achievable enhancements in terms of creative social studies and Islamic education teaching and learning. Therefore, it seems that there is a need to carry out this research.

\section{Statement of the Problem}

It seems that there is a problem of practicing leadership skills by teachers in schools while dealing with students. Therefore, the main issue of this research is to find out how social studies and Islamic education teachers in Jordan demonstrate the leadership practices and creativity traits in the classroom environment.

\section{Research Questions}

The following questions have been investigated:

1) To what extent do SS and IE teachers in Jordan perceive that they demonstrate leadership practices as self reported?

2) To what extent do SS and IE teachers in Jordan perceive that they demonstrate creativity traits as self reported?

3) Is there any relationship between the leadership practices of SS and IE teachers and their creativity traits in Jordan as self reported?

4) Is there any significant difference as $p<.05$ in the leadership practices of SS and IE teachers as self reported according to gender, specialization, educational experience, and stage of schools?

5) Is there any significant difference as $p<.05$ in creativity traits of SS and IE teachers as self reported according to gender, specialization, educational experience, and stage of schools?

\section{Purpose of the Study}

The purpose of this study was to investigate leadership practices as a core of classroom management and creativity traits of social studies and Islamic education teachers in Jordan. This study examined the leadership skills of teachers in the context of the following ten leadership dimensions, that is: 1) Observing a moral value system, 2) Building a positive culture, 3) Managing and leading, 4) Relating with students, 5) Relating with community, and adopting Kouzes and Posner's five dimensions that is 1) Challenging the process, 2) Inspiring a shared vision, 3) Enabling others to act, 4) Modeling the way, and 5) Encouraging the heart. The creativity dimension was comprised of the following eight creativity traits: 1) Passion for work, 2) Independence, 3) Goal setting, 4) Originality, 5) Flexibility, 6) Wide range of interests, 7) Intelligence, and 8) Motivation.

\section{Significance of the Study}

Although there is abundant literature on school leadership studies, there has been less research on teacher leadership and creativity. This study provides more insights on leadership practices and creativity in classrooms. It also seeks to contribute to the development and understanding of educational leadership and in particular social studies and Islamic education teachers' leadership and creativity in Jordanian educational institutions. This will give a better understanding of organizational effectiveness and provide guidelines for teachers to motivate and direct their students toward achieving the school's educational objectives. Furthermore, effective leadership and creativity could be considered as valuable characteristics in the selection, training and recruitment of teachers who are expected to have creativity as a part of their teaching and leadership capacity.

\section{Definition of Terms}

Leadership: Leadership is the process of guiding and influencing members of an organization so that they will display initiative and love for their work and achieve the common objectives of the organization. To support this, leadership, based on Vance Packard's definition is the art of getting others to want to do something that you are convinced should be done (Kouzes \& Posner, 2003). According to Kouzes and Posner, leadership is identified by the following five practices: 1) Challenging the process; 2) inspiring a shared vision; 3) Enabling others to act; 4) Modeling the way; 5) Encouraging the heart. For this study, five more leadership dimensions were added, those are: observing moral value system, building a positive culture, managing and leading, relating with students, and relating with community.

Creativity: creativity is "a special condition, attitude or state of being that reflects Passion for Work, Independence, Goal Setting, Originality, Flexibility, a Wide Range of Interests, average or above-average Intelligence and Motivation” (Goertz, 1991: p. 3).

\section{Delimitations}

The delimitations of this study are as follows:

1) The sample of the study is limited to social studies and Islamic education teachers in Jordan during the 2008-2009 school 
year.

2) The identification of leadership dimensions was based on a review of the available limited literature related to the subject based on the five leadership practices of Kouzes and Posner (2003).

3) The identification of creativity traits was based on a review of the available limited literature related to the subject based on the creativity traits of Goertz's theory (1991).

4) The study is limited to the basic and secondary schools in Jordan and not the kindergarten level.

\section{Limitations}

The limitations of this study are as follows:

1) Leadership practices and creativity traits were measured by perceptions only, and these have their own limitations, particularly the self-perception questionnaires. It is pertinent to note however, that the instruments have been well tested.

2) The study used questionnaires as the main tool for collecting data. Interviews and observations therefore, were not used.

\section{Methods}

\section{Research Design}

A survey method was used to collect data from the respondents of the study. The design of the study included a survey of social studies and Islamic education teachers' self-perceptions through questionnaires. A literature review was used to help identify the main basis of leadership practices as a core of classroom management and creativity.

\section{Population and Sample}

The population of the study comprised of all social studies and Islamic education teachers in the north part of Jordan. A sample of 289 social studies and Islamic education teachers were selected randomly. Table 1 presents the background characteristics of the study sample.

\section{Instrumentation}

The study has adapted and used the following questionnaires in order to gather data for this study:

1) The Leadership Practices Inventory (Self) is a survey developed as an empirical measure of the conceptual leadership framework generated from the case studies of 1100 managers, best personal experiences as leaders reported by Kouzes and Posner (2003). Leadership Practices Inventory (LPI-Self) describes the behavior from the respondents' view.

In order to make this questionnaire more appropriate for the Jordanian culture, the questionnaire was adapted. Based on the review of the literature on educational leadership such as Datnow and Castellano (2001) and Schmiesing (2001), and on consultations with some experts in the field, it was decided to employ ten dimensions. The first five dimensions were added to the five from the original questionnaire that were suitable to be applied in Jordan.

2) The Creativity Self-Perception Questionnaire (CSPQ). This is an instrument developed by Goertz and Lemley (1991), and is based on the selected traits of creativity.

In order to make this questionnaire more appropriate for the
Table 1.

Distribution of teachers according to background characteristics $(\mathrm{N}=$ 289).

\begin{tabular}{|c|c|c|}
\hline Characteristics & $\mathbf{N}$ & Percentage \\
\hline \multicolumn{3}{|l|}{ Gender } \\
\hline Male & 239 & 82.7 \\
\hline Female & 50 & 17.3 \\
\hline \multicolumn{3}{|l|}{ Major } \\
\hline Social Studies & 177 & 61.2 \\
\hline Islamic Studies & 112 & 38.8 \\
\hline \multicolumn{3}{|l|}{ Age } \\
\hline 20 - 30 years & 178 & 61.6 \\
\hline 31 - 40 years & 77 & 26.6 \\
\hline $41-50$ years & 28 & 9.7 \\
\hline 50 years and above & 6 & 2.1 \\
\hline \multicolumn{3}{|l|}{ Educational Level } \\
\hline Diploma & 22 & 7.6 \\
\hline Bachelor & 215 & 74.4 \\
\hline Master’ & 48 & 16.6 \\
\hline Doctoral & 4 & 1.4 \\
\hline \multicolumn{3}{|l|}{ Experience in Education } \\
\hline 1-less than 5 years & 129 & 44.6 \\
\hline 5-less than 10 years & 86 & 29.8 \\
\hline 10 years and above & 74 & 25.6 \\
\hline \multicolumn{3}{|l|}{ Stage of Schools } \\
\hline Basic & 125 & 43.3 \\
\hline Secondary & 164 & 56.7 \\
\hline
\end{tabular}

Jordanian culture, the questionnaire was adapted. Based on the review of the literature on creativity such as Beswick (2008) and Fleith (2000), and on consultation with some experts in the field, it was decided to employ the eight main dimensions of the questionnaire arranged differently. Some items under each dimension were deleted and others were added to make the questionnaire clearer for and more appropriate to the educational settings in Jordan. CSPQ contains a total of 22 items with 8 traits used to measure each of creativity traits.

Responses to the all questionnaires were measured using 5-point Likert scale as follows: 1) Rarely, 2) Once in a While, 3) Sometimes, 4) Fairly Often and 5) Very Frequently.

\section{Variables of the Study}

The dependent variables of the study are: gender, major of specialization, educational experience, and stage of schools. And the independent variables are the ten leadership practices of 1) observing a moral value system, 2) building a positive culture, 3) managing and leading, 4) relating with students, 5) relating with community, 6) challenging the process, 7) inspiring a shared vision, 8) enabling others to act, 9) modeling the way, and 10) encouraging the heart. In addition to the eight creativity traits of 1) passion for work, 2) independence, 3) goal setting, 4) originality, 5) flexibility, 6) wide range of interests, 7) intelli- 
gence, and 8) motivation.

\section{Validity and Reliability of the Questionnaires}

Because the questionnaire was developed and used before, by its designers themselves and other researchers in different places across the world, the validity and the reliability is already developed and assessed. Since the context is different, the language of the questionnaire should be appropriate for the new context. Testing validity is a matter of translating this questionnaire into Arabic language giving the same meanings to the items as in the original English version (to be valid to the Jordanian context). To achieve this aim, the researchers: translated the questionnaire (English copy into Arabic; submitted the translated copy to some of their specialized colleagues who are good with English to check and correct their translation; considered all of the friends' comments; then, gave it to one of the professional auditor to audit the translated copy; gave the Arabic copy to someone not involved in the original translation; after that the researchers compared the original one with the new one to find out to what extent they are corresponded; and before distributing the questionnaires the researchers sent the questionnaires (Arabic copy) to more than ten educational experts in some of the Jordanian institution to check it and asking them if there is any comments about the statements. Most of them agree that they are good, clear and understandable. The reliability of the two questionnaires was assessed through the use of Conbrach's alpha coefficient. A pilot study was conducted on 20 teachers among the population of the study. A test and retest method was used in two weeks. Thus, the Leadership Practices Inventory Conbrach's alpha coefficient was .94, and for the Creativity Self-Perception Questionnaire (CSPQ) was .90 (Table 2).

\section{Data Analysis}

For analyzing data obtained from the two instruments (CSPQ) and (LPI-Self), the Statistics Package for the Social Sciences (SPSS) was used. Frequencies, percentages, Independent Sample $t$-test, analysis of variance, ANOVA and Pearson productmoment correlation coefficient were used to answer the research questions.

\section{Study Results}

The results of the study were demonstrated in accordance with its questions, as follows:

\section{Research Question 1}

To what extent do SS and IE teachers in Jordan perceive that they demonstrate leadership practices as self reported?

Analysis of the results from the Leadership Practices Inventory (LPI-Self) revealed that teachers perceived themselves positively in all dimensions. The means ranged from 3.37; (the lowest) to 4.27; (the highest) and were overall quite high. While the Relating with Community dimension got the lowest, the Encouraging the Heart dimension was perceived as the highest. Details of the teachers' perceptions for the ten leadership dimensions are displayed in Table 3.

Table 3 shows that the Encouraging the Heart dimension was perceived as having the highest (4.27) as practiced by the teachers among the ten leadership dimensions. This was fol-
Table 2.

Represents reliability of the (LPI-Self) and (CSPQ).

\begin{tabular}{cc}
\hline Questionnaires & Coefficient Alpha \\
\hline Leadership Practices Inventory (LPI-Self) & .94 \\
Creativity Self-Perception Questionnaires (CSPQ) & .90 \\
\hline
\end{tabular}

Table 3.

Teachers' perceptions of their leadership practices by dimension $(\mathrm{N}=$ 289).

\begin{tabular}{cccc}
\hline Dimensions & Means & $\begin{array}{c}\text { Standard } \\
\text { Deviation }\end{array}$ & Range \\
\hline Observing Moral Value System & 4.21 & .52 & 2 \\
Building a Positive Culture & 4.04 & .62 & 4 \\
Managing and Leading & 3.58 & .65 & 8 \\
Relating with Students & 3.94 & .72 & 5 \\
Relating with Community & 3.37 & .98 & 10 \\
Challenging the Process & 3.64 & .82 & 7 \\
Inspiring a Shared Vision & 3.57 & .86 & 9 \\
Enabling Others to Act & 3.92 & .62 & 6 \\
Modeling the Way & 4.11 & .68 & 3 \\
Encouraging the Heart & 4.27 & .67 & 1 \\
Leadership Practices & 3.84 & .50 & \\
\hline
\end{tabular}

lowed by the Observing Moral Value System dimension that scored 4.21. With an almost similar percentage, the Modeling the Way got 4.11 as perceived by the teachers. Building a Positive Culture came in the fourth with 4.04 followed by Relating with Students (3.94). Sixth came, Enabling Others to Act with 3.92 followed by Challenging the Process with 3.64. Managing and Leading came next with 3.58. This was followed by Inspiring a Shared Vision which came in ninth with 3.57 followed by the final dimension that is relating with community with 3.37.

\section{Research Question 2}

To what extent do SS and IE teachers in Jordan perceive that they demonstrate creativity traits as self reported?

Analysis of the results from the Creativity Self-Perception Questionnaire (CSPQ) revealed that teachers think they demonstrated all creativity traits positively. The means ranged from 3.80; (the lowest) to 4.13; (the highest) and are reasonably high overall. While the trait of Wide Range of Interests got the lowest percentage, Passion for Work was perceived as the highest. Details of the teachers' perceptions for the eight creativity traits are displayed in Table 4.

Table 4 shows that teachers think Passion for Work trait was the most frequently practiced creative trait as demonstrated by them with the highest percentage (4.13). This was followed by Motivation (4.08). Independence came in third with 4.02 followed by Originality with 3.93 . In fifth was Flexibility with 3.83. Intelligence came next with 3.82 followed in seventh by the trait of Goal Setting with 3.81. Finally, Wide Range of Interests came lowest with 3.80 . 
Table 4.

Shows teachers' perceptions of their creativity traits by dimension $(\mathrm{N}=$ 289).

\begin{tabular}{cccc}
\hline Traits & Means & Standard Deviation & Range \\
\hline Passion for Work & 4.13 & .56 & 1 \\
Independence & 4.02 & .63 & 3 \\
Goal Setting & 3.81 & .75 & 7 \\
Originality & 3.93 & .77 & 4 \\
Flexibility & 3.83 & .76 & 5 \\
Wide Range of Interests & 3.80 & .84 & 8 \\
Intelligence & 3.82 & .87 & 6 \\
Motivation & 4.08 & .76 & 2 \\
Creativity Traits & $\mathbf{3 . 9 4}$ & .53 &
\end{tabular}

\section{Research Question 3}

Is there any relationship between the leadership practices of SS and IE teachers and their creativity traits in Jordan as self reported?

The data related to this question were obtained from teachers' responses to the Leadership Practices Inventory (LPI-Self) and Creativity Self-Perception Questionnaire (CSPQ). To answer this question, Pearson's Correlation analysis was used between the final results of the ten leadership dimensions and the eight creativity traits of teachers.

As presented in Table 5, analysis of the results of the Pearson Correlation from the Leadership Practices Inventory (LPISelf) and Creativity Self-Perception Questionnaire (CSPQ) revealed that the correlation between the results of the ten leadership dimensions together and the eight creativity traits of teachers was positively significant with $\mathrm{r}=.62, p<.01$ according to the teachers' perceptions about themselves.

\section{Research Question 4}

Is there any significant difference as $p<.05$ in the leadership practices of SS and IE teachers as self reported according to gender, specialization, educational experience, and stage of schools?

The data related to this section was obtained from teachers' responses to the Leadership Practices Inventory (LPI-Self). To answer the research question, an Independent Sample $t$-test was used in order to find out if there are significant differences between the male and female teachers' perceptions regarding the ten leadership dimensions. The results of the analysis of teachers' perceptions for the ten leadership dimensions by gender are displayed in Table 6 .

The results show that there were significant differences between gender and the Relating with Community dimension; $p<.05$. It shows also that there were no significant differences between gender and the other nine leadership dimensions.

\section{Teachers’ Perceptions of Their Leadership Practices by Major of Specialization}

To answer the research question, an Independent Sample $t$ test was used in order to find out if there are significant differences between Social Studies and Islamic Education teachers'
Table 5.

Shows the relationship between the leadership dimensions and the creativity traits according to the teachers' perceptions $(\mathrm{N}=289)$.

\begin{tabular}{cc}
$\begin{array}{c}\text { Creativity Traits \& } \\
\text { Leadership Practices }\end{array}$ & Correlation \\
\cline { 2 - 2 } & $.62^{* *}$ \\
\hline
\end{tabular}

Note: ${ }^{* *} p<.01$.

Table 6.

Shows means and standard deviations and t-test of teachers' perceptions of their leadership practices by gender $(\mathrm{N}=289)$.

\begin{tabular}{|c|c|c|c|c|c|c|}
\hline \multirow[t]{2}{*}{ Dimensions } & \multicolumn{2}{|c|}{ Male } & \multicolumn{2}{|c|}{ Female } & & \multirow{2}{*}{ Sig. } \\
\hline & M & SD & $\mathbf{M}$ & SD & & \\
\hline Observing Moral Value System & 4.20 & .520 & 4.27 & .520 & .414 & .521 \\
\hline Building a Positive Culture & 4.02 & .623 & 4.13 & .600 & 1.431 & .233 \\
\hline Managing and Leading & 3.57 & .679 & 3.62 & .451 & .636 & .426 \\
\hline Relating with Students & 3.94 & .741 & 3.93 & .587 & .101 & .751 \\
\hline Relating with Community & 3.31 & .979 & 3.69 & .933 & 7.690 & .006 \\
\hline Challenging the Process & 3.65 & .805 & 3.60 & .878 & .029 & .866 \\
\hline Inspiring a Shared Vision & 3.60 & .837 & 3.45 & .937 & .851 & .357 \\
\hline Enabling Others to Act & 3.93 & .630 & 3.87 & .602 & .925 & .337 \\
\hline Modeling the Way & 4.09 & .678 & 4.20 & .700 & 1.039 & .309 \\
\hline Encouraging the Heart & 4.28 & .645 & 4.25 & .810 & .020 & .889 \\
\hline Leadership Practices & 3.83 & .509 & 3.89 & .426 & .616 & .433 \\
\hline
\end{tabular}

Note: $\mathrm{M}=$ Mean, $\mathrm{SD}=$ Standard Deviation, ${ }^{*} p<.05$.

perceptions regarding the ten leadership dimensions. The results of the analysis of teachers' perceptions for the ten leadership dimensions by major of specialization are displayed in Table 7.

The results show that there were no significant differences between major of specialization and all the leadership dimensions.

\section{Teachers' Perceptions of Their Leadership Practices by Educational Experience}

The data related to this question was obtained from teachers responses to the Leadership Practices Inventory (LPI-Self). To answer the research question, the one-way analysis of variance (ANOVA) was used in order to find out if there are significant differences between the teachers' perceptions by four categories of educational experience regarding the ten leadership dimensions. The results are displayed in Table 8.

One-way analysis of variance (ANOVA) was performed using the ten leadership dimensions as dependent variables in the statistical analysis and educational experience as the independent variable. As can be noted, there were significant differences between the educational experience of the teachers and their perceptions on the Managing and Leading and Relating with Students dimensions. The above-mentioned table shows that the experienced teachers group with "6-less than 10 years" were perceived themselves as better than the other two groups perceived themselves. It also shows that there were no significant differences between the educational experience of the teachers and their perceptions on the other eight dimensions. 
Table 7.

Shows means and standard deviations and ANOVA F-tests of teachers' perceptions of their leadership practices by major of specialization $(\mathrm{N}=$ 289).

\begin{tabular}{|c|c|c|c|c|c|c|}
\hline \multirow{2}{*}{$\begin{array}{l}\text { Leadership } \\
\text { Dimensions }\end{array}$} & \multicolumn{2}{|c|}{$\begin{array}{l}\text { Social } \\
\text { Studies }\end{array}$} & \multicolumn{2}{|c|}{$\begin{array}{c}\text { Islamic } \\
\text { Education }\end{array}$} & \multirow{2}{*}{$\mathbf{F}$} & \multirow{2}{*}{ Sig. } \\
\hline & $\mathbf{M}$ & SD & $\mathbf{M}$ & SD & & \\
\hline $\begin{array}{l}\text { Observing Moral Value } \\
\text { System }\end{array}$ & 4.17 & .477 & 4.27 & .577 & 2.072 & .151 \\
\hline Building a Positive Culture & 4.00 & .607 & 4.10 & .637 & .992 & .320 \\
\hline Managing and Leading & 3.62 & .633 & 3.50 & .661 & 2.114 & .147 \\
\hline Relating with Students & 3.97 & .668 & 3.89 & .786 & .246 & .620 \\
\hline Relating with Community & 3.41 & .981 & 3.32 & .981 & 1.089 & .298 \\
\hline Challenging the Process & 3.68 & .759 & 3.58 & .902 & .760 & .384 \\
\hline Inspiring a Shared Vision & 3.63 & .788 & 3.48 & .949 & .767 & .382 \\
\hline Enabling Others to Act & 3.92 & .568 & 3.90 & .707 & .022 & .882 \\
\hline Modeling the Way & 4.12 & .662 & 4.09 & .714 & .028 & .868 \\
\hline Encouraging the Heart & 4.33 & .531 & 4.18 & .849 & 3.174 & .076 \\
\hline Leadership Practices & 3.86 & .448 & 3.81 & .563 & .428 & .514 \\
\hline
\end{tabular}

Table 8.

Means and standard deviations and ANOVA F-tests of teachers' perceptions of their leadership practices by educational experience $(\mathrm{N}=$ 289).

\begin{tabular}{|c|c|c|c|c|c|c|c|c|}
\hline \multirow[t]{2}{*}{$\begin{array}{l}\text { Leadership } \\
\text { Dimensions }\end{array}$} & \multicolumn{2}{|c|}{$\begin{array}{l}\text { 1-Less } \\
\text { than } 6 \\
\text { Years }\end{array}$} & \multicolumn{2}{|c|}{$\begin{array}{c}\text { 6-Less } \\
\text { than } 10 \\
\text { Years }\end{array}$} & \multicolumn{2}{|c|}{$\begin{array}{l}\text { More than } \\
10 \text { Years }\end{array}$} & \multirow[t]{2}{*}{$\mathbf{F}$} & \multirow[t]{2}{*}{ Sig. } \\
\hline & $\mathbf{M}$ & SD & $\mathbf{M}$ & SD & $\mathbf{M}$ & SD & & \\
\hline $\begin{array}{l}\text { Observing Moral Value } \\
\text { System }\end{array}$ & 4.20 & .562 & 4.24 & .468 & 4.21 & .504 & .260 & .771 \\
\hline Building a Positive Culture & 3.98 & 683 & 4.08 & .566 & 4.09 & .558 & 1.376 & .254 \\
\hline Managing and Leading & 3.45 & .672 & 3.83 & .551 & 3.50 & 620 & 9.477 & .000 \\
\hline Relating with Students & 3.93 & .720 & 4.12 & .646 & 3.75 & .742 & 5.333 & .005 \\
\hline Relating with Community & 3.23 & .994 & 3.62 & .944 & 3.33 & .956 & 3.430 & .034 \\
\hline Challenging the Process & 3.53 & .868 & 3.81 & .721 & 3.65 & .807 & 2.903 & .057 \\
\hline Inspiring a Shared Vision & 3.43 & .885 & 3.77 & .823 & 3.59 & .804 & 1.926 & .148 \\
\hline Enabling Others to Act & 3.94 & 615 & 4.02 & .626 & 3.77 & .619 & 3.675 & .027 \\
\hline Modeling the Way & 4.04 & .779 & 4.25 & .614 & 4.06 & .545 & 1.727 & .180 \\
\hline Encouraging the Heart & 4.34 & 672 & 4.25 & .690 & 4.19 & .660 & 1.186 & .307 \\
\hline Leadership Practices & 3.77 & .516 & 3.99 & .488 & 3.79 & .431 & 4.760 & .009 \\
\hline
\end{tabular}

Note: MS = Mean Square, ${ }^{*} p<.05$.

\section{Teachers' Perceptions of Their Leadership Practices by Stage of Schools}

The data related to this question were obtained from teachers' responses to the Leadership Practices Inventory (LPI-Self). To answer the research question, the Independent Sample $t$-test was used in order to find out if there are significant differences be- tween the basic and secondary school teachers' perceptions regarding the ten leadership dimensions. The results of the analysis of teachers' perceptions for the ten leadership dimensions by stage of schools are displayed in Table $\mathbf{9}$.

The results show that there was significant difference between teachers' perceptions in basic and secondary schools regarding the Inspiring a Shared Vision, while there was no evidence of any significant differences with the other nine leadership dimensions.

\section{Research Question 5}

Is there any significant difference as $p<.05$ in creativity traits of SS and IE teachers as self reported according to gender, specialization, educational experience, and stage of schools?

Teachers' Perceptions of Their Creativity Traits by Gender

The data related to this question was obtained from teachers' responses to the Creativity Self Perception Questionnaire (CSPQ). To answer the research question, the Independent Sample $t$-test was used in order to find out if there are significant differences between the male and female teachers' perceptions regarding the eight creativity traits. The results of the analysis of teachers' perceptions for the eight creativity traits by gender are displayed in Table 10.

The results show that there was no significant difference between the teachers' creativity traits regarding their gender. The table mentioned above showed that female teachers have perceived themselves having five creativity traits better than male, while male perceived themselves better in the last three.

\section{Teachers' Perceptions of Their Creativity Traits by Major of Specialization}

The data related to this question was obtained from teachers' responses to the Creativity Self Perception Questionnaire (CSPQ). To answer the research question, the one-way analysis of variance ANOVA was used in order to find out if there are significant differences between the teachers' perceptions by the two categories of major of specialization regarding the eight creativity traits. The eight creativity traits were used as dependent variables and major of specialization as the independent variable. The results of the analysis of teachers' perceptions for the eight creativity traits by major of specialization are displayed in Table $\mathbf{1 1}$.

The results indicated that there were no significant differences between the major of specialization of the teachers and their self perceptions on all of the eight creative traits.

\section{Teachers' Perceptions of Their Creativity Traits by Educational Experience}

As shown in Table 12, the results indicated that there were significant differences between the educational experience of the teachers and their self perceptions on six creative traits of Passion for Work, Independence, Goal Setting, Flexibility, Wide Range of Interests and Intelligence. It indicates also that there was no significant difference between the educational experience of the teachers and their self perceptions on the other two creative traits of Originality and Motivation.

\section{Teachers' Perceptions of Their Creativity Traits by Stage of Schools}

The data related to this question was obtained from teachers' responses to the Creativity Self-Perception Questionnaire (CSPQ). 
Table 9.

Shows means and standard deviations and t-tests of leadership practices between basic and secondary school teachers as perceived by themselves $(\mathrm{N}=289)$.

\begin{tabular}{|c|c|c|c|c|c|c|}
\hline \multirow[t]{2}{*}{ Dimensions } & \multicolumn{2}{|c|}{ Basic } & \multicolumn{2}{|c|}{ Secondary } & \multirow{2}{*}{$\mathbf{F}$} & \multirow{2}{*}{ Sig. } \\
\hline & $\mathbf{M}$ & SD & $\mathbf{M}$ & SD & & \\
\hline $\begin{array}{l}\text { Observing Moral Value } \\
\text { System }\end{array}$ & 4.22 & .564 & 4.20 & .484 & .097 & .755 \\
\hline Building a Positive Culture & 4.05 & .659 & 4.03 & .589 & .528 & .468 \\
\hline Managing and Leading & 3.52 & .648 & 3.62 & .642 & .070 & .791 \\
\hline Relating with Students & 3.89 & .831 & 3.98 & .613 & .919 & .339 \\
\hline Relating with Community & 3.26 & 1.013 & 3.46 & .948 & 1.024 & .312 \\
\hline Challenging the Process & 3.60 & .855 & 3.67 & .788 & .000 & .994 \\
\hline Inspiring a Shared Vision & 3.36 & .884 & 3.74 & .797 & 9.938 & .002 \\
\hline Enabling Others to Act & 3.90 & .727 & 3.93 & .535 & .315 & .575 \\
\hline Modeling the Way & 3.99 & .788 & 4.20 & .574 & 5.022 & .026 \\
\hline Encouraging the Heart & 4.27 & .723 & 4.27 & .638 & .052 & .821 \\
\hline Leadership Practices & 3.79 & .548 & 3.88 & .449 & .505 & .478 \\
\hline
\end{tabular}

Note: $\mathrm{M}=$ Mean, $\mathrm{SD}=$ Standard Deviation, ${ }^{*} p<.05$.

Table 10.

Means and standard deviations and t-tests of teachers' perceptions of their creativity traits by gender $(\mathrm{N}=289)$.

\begin{tabular}{ccccccc}
\hline \multirow{2}{*}{ Dimensions } & \multicolumn{2}{c}{ Male } & \multicolumn{2}{c}{ Female } & \multirow{2}{*}{ F } & Sig. \\
\cline { 1 - 5 } & M & SD & M & SD & & \\
\hline Passion for Work & 4.11 & .585 & 4.20 & .436 & .420 & .518 \\
Independence & 4.02 & .654 & 4.03 & .521 & .001 & .977 \\
Goal Setting & 3.78 & .797 & 3.95 & .463 & 1.077 & .300 \\
Originality & 3.90 & .808 & 4.09 & .509 & 2.076 & .151 \\
Flexibility & 3.82 & .795 & 3.87 & .579 & .006 & .937 \\
Wide Range of Interests & 3.81 & .856 & 3.74 & .758 & 1.353 & .246 \\
Intelligence & 3.87 & .843 & 3.62 & .951 & 4.863 & .028 \\
Motivation & 4.09 & .787 & 4.04 & .648 & .324 & .570 \\
Creativity Traits & $\mathbf{3 . 9 3}$ & $\mathbf{. 5 6 5}$ & $\mathbf{3 . 9 7}$ & $\mathbf{. 3 4 3}$ & $\mathbf{. 0 0 0}$ & $\mathbf{. 9 9 8}$ \\
\hline
\end{tabular}

Note: $\mathrm{M}=$ Mean, $\mathrm{SD}=$ Standard Deviation, ${ }^{*} p<.05$.

The Independent Sample $t$-test was used in order to find out if there are significant difference between teachers' perceptions in basic and secondary schools regarding the eight creativity traits. The results of the analysis of teachers' perceptions for the eight creativity traits by stage of schools are displayed in Table 13.

The results show that there were significant differences between teachers' perceptions in basic and secondary schools regarding the creativity traits of Passion for Work, Goal Setting, Wide Range of Interests, Intelligence and Motivation. It indicates also that there was no evidence of any significant difference between the teacher's perceptions in basic and secondary schools regarding the
Table 11.

Shows means and standard deviations and ANOVA F-tests of teachers' perceptions of their creativity traits by major of specialization $(\mathrm{N}=$ 289).

\begin{tabular}{ccccccc}
\hline & \multicolumn{2}{c}{$\begin{array}{c}\text { Social } \\
\text { Studies }\end{array}$} & \multicolumn{2}{c}{$\begin{array}{c}\text { Islamic } \\
\text { Education }\end{array}$} & F & Sig. \\
\cline { 2 - 5 } & $\mathbf{M}$ & SD & M & SD & & \\
\hline Passion for Work & 4.09 & .553 & 4.19 & .573 & 3.177 & .076 \\
Independence & 4.04 & .619 & 4.00 & .655 & .015 & .903 \\
Goal Setting & 3.77 & .766 & 3.86 & .729 & 1.548 & .214 \\
Originality & 3.90 & .785 & 3.98 & .739 & .580 & .447 \\
Flexibility & 3.84 & .691 & 3.81 & .865 & .006 & .940 \\
Wide Range of Interests & 3.77 & .831 & 3.85 & .854 & 2.642 & .105 \\
Intelligence & 3.80 & .866 & 3.86 & .868 & 2.085 & .150 \\
Motivation & 4.11 & .766 & 4.05 & .763 & .000 & .986 \\
Creativity Traits & $\mathbf{3 . 9 3}$ &. $\mathbf{5 2 0}$ & $\mathbf{3 . 9 6}$ & $\mathbf{. 5 5 4}$ & $\mathbf{1 . 2 1 8}$ & .271 \\
\hline
\end{tabular}

Note: $\mathrm{M}=$ Mean, $\mathrm{SD}=$ Standard Deviation, ${ }^{*} p<.05$.

Table 12.

Shows means and standard deviations and ANOVA F-tests of teachers' perceptions of their creativity traits by educational experience $(\mathrm{N}=$ 289).

\begin{tabular}{|c|c|c|c|c|c|c|c|c|}
\hline \multirow{2}{*}{$\begin{array}{l}\text { Creativity } \\
\text { Traits }\end{array}$} & \multicolumn{2}{|c|}{$\begin{array}{l}\text { 1-Less than } \\
6 \text { Years }\end{array}$} & \multicolumn{2}{|c|}{$\begin{array}{l}\text { 6-Less than } \\
10 \text { Years }\end{array}$} & \multicolumn{2}{|c|}{$\begin{array}{l}\text { More than } \\
10 \text { Years }\end{array}$} & \multirow[t]{2}{*}{$\mathbf{F}$} & \multirow[t]{2}{*}{ Sig. } \\
\hline & $\mathbf{M}$ & SD & $\mathbf{M}$ & SD & $\mathbf{M}$ & SD & & \\
\hline Passion for Work & 4.04 & & & & & .544 & & .014 \\
\hline Independence & 3.93 & .657 & 4.23 & .572 & 3.94 & .604 & 6.017 & .003 \\
\hline Goal Setting & 3.76 & .779 & 3.98 & .664 & 3.68 & .774 & 3.235 & .041 \\
\hline Originality & 3.88 & .811 & 4.04 & .687 & 3.90 & .776 & .879 & .416 \\
\hline Flexibility & 3.79 & .733 & 4.04 & .635 & 3.65 & .889 & 5.340 & .005 \\
\hline $\begin{array}{l}\text { Wide Range of } \\
\text { Interests }\end{array}$ & 3.70 & .777 & 4.13 & .868 & 3.59 & .810 & 10.061 & .000 \\
\hline Intelligence & 3.66 & .868 & 4.13 & .841 & 3.76 & .808 & 6.476 & .002 \\
\hline Motivation & 4.00 & .799 & 4.24 & .728 & 4.05 & .724 & 1.539 & .216 \\
\hline Creativity Traits & 3.86 & .544 & 4.14 & .475 & 3.85 & .523 & 7.393 & .001 \\
\hline
\end{tabular}

Note: $\mathrm{M}=$ Mean, $\mathrm{SD}=$ Standard Deviation, ${ }^{*} p<.05$.

creativity traits of Independence, Originality and Flexibility.

\section{Discussion}

According to the perceptions of social studies and Islamic education teachers, the results have shown that teachers were perceived, by themselves, to be practicing all the leadership dimensions and possess the creativity traits studied. This very encouraging result also gave rise to the following observations according to the research questions:

\section{Research Question 1}

To what extent do SS and IE teachers in Jordan perceive that they demonstrate leadership practices as self reported? With regard to the perceptions towards leadership practices, it 
Table 13.

Shows means and standard deviations and t-test of creativity traits between basic and secondary school teachers as perceived by themselves $(\mathrm{N}=289)$.

\begin{tabular}{|c|c|c|c|c|c|c|}
\hline \multirow{2}{*}{ Dimensions } & \multicolumn{2}{|c|}{$\begin{array}{c}\text { Basic } \\
(\mathrm{N}=125)\end{array}$} & \multicolumn{2}{|c|}{$\begin{array}{c}\text { Secondary } \\
(\mathbf{N}=164)\end{array}$} & \multirow[t]{2}{*}{$\mathbf{F}$} & \multirow{2}{*}{ Sig. } \\
\hline & $\mathbf{M}$ & SD & $\mathbf{M}$ & SD & & \\
\hline $\begin{array}{l}\text { Passion } \\
\text { for Work }\end{array}$ & 4.03 & .592 & 4.21 & .526 & 5.422 & .021 \\
\hline Independence & 3.94 & .655 & 4.09 & .609 & 1.878 & .172 \\
\hline Goal Setting & 3.70 & .819 & 3.88 & .690 & 3.902 & .049 \\
\hline Originality & 3.87 & .817 & 3.98 & .726 & .890 & .346 \\
\hline Flexibility & 3.73 & .887 & 3.91 & .642 & 3.616 & .058 \\
\hline $\begin{array}{l}\text { Wide Range of } \\
\text { Interests }\end{array}$ & 3.62 & .866 & 3.94 & .793 & 10.040 & .002 \\
\hline Intelligence & 3.62 & .880 & 3.98 & .823 & 10.005 & .002 \\
\hline Motivation & 3.86 & .793 & 4.26 & .695 & 17.669 & .000 \\
\hline Creativity Traits & 3.81 & .588 & 4.04 & .465 & 10.721 & .001 \\
\hline
\end{tabular}

Note: $\mathrm{M}=$ Mean, $\mathrm{SD}=$ Standard Deviation.

may be seen that while the categories of behavior pertaining to traditional aspects of educational leadership, viz. "Encouraging the Heart, Observing Moral Value System, Modeling the Way" and "Building a Positive Culture, were perceived by teachers themselves to be highly practiced, those categories of behavior pertaining to modern elements of leadership, most notably represented by "Relating with Community and Inspiring a Shared Vision" were perceived by teachers to be less practiced, suggesting more emphasis on moral aspects of leadership. Giving more attention to the modern leadership elements mentioned above may allow social studies and Islamic education teachers to benefit from ideas developed and refined by western scholars to further improve their perceptions of their practices as classroom leaders towards world class standards, at the same time maintaining their moral priorities. In terms of providing an effective learning environment in a classroom in its complex endeavor, research findings continuously have shown that the key to successful management is the teacher's ability to manage the classroom and to organize instruction (Brophy, 1983, 1988; Brophy \& Alleman, 1998).

\section{Research Question 2}

To what extent do SS and IE teachers in Jordan perceive that they demonstrate creativity traits as self reported?

The result of the present study revealed that to some extent, the perceptions of social studies and Islamic education teachers of the schools in Jordan indicated that teachers had and practiced the eight creativity traits. However, the ideal situation should be when the teachers have and practice these creativity traits to a very high level. As for Passion for Work, social studies and Islamic education teachers as classroom leaders should be committed to those things that they believe in. They should have persistence in working through the solution to a problem. Demonstration of enthusiasm for what teachers do is essential in having the passion for work at the classrooms.

\section{Research Question 3}

Is there any relationship between the leadership practices of SS and IE teachers and their creativity traits in Jordan as self reported?

The correlation between the results of the ten leadership dimensions together and the eight creativity traits of teachers was positively significant. This relationship means that wherever the ten leadership dimensions are found, the creativity traits will be identified and vice versa. In other words, the teachers who think they are exhibiting the leadership dimensions will easily display the creativity traits and vice versa. This proposed that teachers' perceptions might indicate that the more leadership dimensions they practice, the more creative they could be.

\section{Research Question 4}

Is there any significant difference as $p<.05$ in the leadership practices of SS and IE teachers as self reported according to gender, specialization, educational experience, and stage of schools?

The factor concerning gender gave rise to some very interesting observations. Apparently, there is an overall difference between female and males' teachers' perceptions in practicing leadership domains; female teachers perceived themselves better than males. Particularly, the difference was seen between female and male teachers regarding the practice of "Relating with Community" domain. This could possibly attribute to the females' emotional nature. For Wilson (1992) human females tend to be higher than males in empathy, verbal skills, and social skills. Consequently, female teachers are more likely to promote greater attention of social and affective aspects whether inside or out side schools. Consistent with the objectives and aims of teaching Islamic and social studies aspects, the quality of being sociable is presumed as the most important feature of the Islamic and social studies teachers. They should have a sound social philosophy and they should make their best contribution to the society. Islamic and socials studies teachers with responsibility for helping children and young people are required to help students respect each other's values, thoughts, and differences (Ross, 2006).

Meanwhile, the analysis revealed that there was no significant difference regarding the variable of specialization. This might be due to the nature of the subject matter knowledge of the both areas, since the core of this knowledge area revolves around human value system. Moreover, in the literature social studies, religious education aspects are deemed as part of social studies content knowledge (Ross, 2006).

With regard to the educational experience variable, the analysis showed that there was a significant difference between the three groups of teachers with reference to "Managing and Leading" and "Relating with Students" dimensions. Experienced teachers group with "6-less than 10 years" were better than the other two groups. For the researchers, this group of teachers can be more effective than the others. Teachers at this level of experience might be seen as enthusiastic, motivated and have ample opportunities to communicate (Rice, 2010). For Hersey (2002), there is a strong correlation between the leadership practices and the motivation. Teachers might be able to work cooperatively and communicate effectively with students and share with others e.g. parents, and other members of the community. To help students engage in the classroom decision- 
making processes, teachers ought to allow open discussions and exchange of views and practice the shura (consultation) before making decisions. For Tinzman, Jones, Fennimore, Bakker, Fine, and Pierce (1990) students' engagement in the classroom's decisions lead to higher group and individual achievement, higherquality reasoning strategies, more frequent transfer of these from the group to individual members, more metacognition, and more new ideas and solutions to problems. Since deal closely with students, they have a strong influence on their trust and confidence.

According to teachers' perceptions, secondary social studies and Islamic education teachers were better than basic school teachers in practicing "Inspiring a Shared Vision”. This result might be justified regarding students level in the secondary stage that teachers deal with. Mooney (2000) cited that students who come to this stage are reasonably well prepared with adequate academic skills to gain higher levels of literacy, knowledge, skills and values, the core elements of school education. In addition the levels of thinking of abstract concepts and establishing social identity and importance of peer group would increase substantially. Secondary students might be more obedient, understandable and aware of their teachers' instructions. Also, they are concerned with achieving a high level of performance (Dahar et al., 2010). On the other hand, teachers' perceptions shown that secondary school teachers were better than basic school teachers in practicing all of the creativity traits. Therefore, students' characteristics in this stage ought to affect and develop both teachers' perceptions of creativity traits and their leadership practices.

\section{Research Question 5}

Is there any significant difference as $p<.05$ in creativity traits of SS and IE teachers as self reported according to gender, specialization, educational experience, and stage of schools?

Although, the results showed that there was no significant difference between the teachers' creativity traits regarding their gender, apparently, female teachers were practicing most of the creativity traits better than the males except for Wide Range of Interests, Intelligence and Motivation. These findings are inconsistent with the results of Spiel and Von Korff's (1998) study, which reported that male teachers mostly associated "novelty" with creativity. Besides, Stoycheyva's work (1996) that female mostly associate idea to creativity, whilst males mainly focus on the aspect of "innovation". In addition, males use the concept of "desire" as important in creativity and females frequently describe creativity by what it is not.

Islamic education teachers were found to be perceived the creativity traits better than social studies teachers except for Independence, Flexibility and Motivation. Although there were no significant differences regarding this variable, the results could be justified due to the fact that Islamic education teachers' subject content knowledge is mainly concerned in religious rules and teachings.

According to the results, there was a significant difference between teachers with different teaching experiences. Experienced teachers group with "6-less than 10 years" were better than the other two groups in connection to the Independence, Flexibility, Wide Range of Interests, and Intelligence domains. Teacher at this level show determined intellectual curiosity and interest in achieving a higher level of success in their classroom interactions. They seem to perceive themselves as creative teachers who generate a great deal of enthusiasm and productivity. Teachers at this level might be considered as productive teacher. Being a productive teacher was argued by Brophy (1983) to be reactive rather than proactive, listening to students and shaping teaching in directions. These characteristics reflects who teachers flexible and Independent are.

Accordingly, taking creativity traits and leadership practices into a proper consideration, social studies and Islamic education teachers will be able to lead and mange their classrooms effectively and successfully, as long as they adhere to the dimensions mentioned above. Teachers will be able to lead their respective classrooms in a way that allow them to cope with the daily changes and be ready to face the future.

\section{Recommendations}

Although the researchers dealt with the topic in all earnestness, there are many limitations in terms of their knowledge and time framework. Therefore, this work is still far from perfect and complete in studying the leadership and creativity of teachers in Jordan. The researchers, therefore, would suggest the following recommendations to enhance the status of educational leadership and creativity:

1) Courses on educational leadership in universities, colleges and teachers training institutions should incorporate the skills of classroom management, leadership and creativity. This will enable these institutions to produce sound, knowledgeable and skillful teachers and administrators who are able to serve Jordanian society.

2) Social studies and Islamic education teachers in educational institutions should practice the right way of classroom leadership. They should be competent and possess good character (manner) so that they can be role models for others especially the younger generation.

3) Social studies and Islamic education teachers as educational leaders should make a great effort to create a sound and healthy environment for their educational organization. Such an environment will help to accomplish the objectives of the institution.

4) The ten leadership dimensions that have been studied could be a guideline for selecting new teachers for the schools. Creativity traits could be considered as criteria of the evaluation process for the school teachers.

5) As the study focused on classroom leadership and creativity of the teachers and their relationships with the students, a study could be carried out to focus on the relationship between the leadership dimensions and the students' achievements on one hand, and the relationship between the creativity traits of the teachers and the students' achievements on the other hand.

\section{REFERENCES}

Al-Hammadi, A. (1996). The spark of creativity. Beirut: Dar Ibn Hazm. Al-Mazeidy, Z. M. (1993). An introduction to the methodology of creativity: An Islamic point of view. Cairo: Dar Al-Wafa' Littiba'a wa Al-Nashr.

Al-Safi, A. T. (1997). Creative thinking: A theory and practice. Jeddah: Matabi’ Dar Al-Bilad.

Al-Sorour, N. H. (2002). Introduction in creativity. Dar Wa'el Fort Publishing.

Anderman, L. H., \& Midgley, C. (1998) Motivation and middle school students [ERIC digest]. Champaign, IL: ERIC Clearinghouse on 
Elementary and Early Childhood Education.

Aubrey, J. V. (1992). The principal's leadership role in effective site-based managed elementary schools. Unpublished Doctoral Dissertation, Bridgeport, CT: University of Bridgeport.

Beare, H., Coldwell, B. J., \& Millikan, R. H. (1989). Creating an excellent school, some new management techniques. London: Routhedge.

Beekun, R. I. and Badawi, J. (1999). Leadership: An Islamic perspective. Beltsville, MD: Amana Publishers.

Beswick (2008). Fostering creativity by establishing the conditions for complex emergence. Proceedings of the Discussing Group 9: Promoting Creativity for All Students in Mathematics Education, The 11th International Congress on Mathematical Education Monterrey, Mexico, 6-13 July 2008.

Blumberg, A. and Greenfield, W. (1986). The effective principal perspectives on school leadership (2nd Edition). Boston, MA: Allyn and Bacon.

Brophy, J., \& Alleman, J. (1998). Classroom management in a social studies learning community. Social Education, 62, 23-34.

Brophy, J. (1983). Classroom organization and management. Elementary School Journal, 83, 265-285.

http://dx.doi.org/10.1086/461318

Brophy, J. (1988). Educating teachers about managing classrooms and students. Teaching and Teacher Education, 4, 1-18. http://dx.doi.org/10.1016/0742-051X(88)90020-0

Carter, M. (1992). Training teachers for creative learning experiences. Child Care Information Exchange, 85, 38-40.

Cavaliere, V. (1995). Leadership practices of principals from distinguished and nondistinguished middle schools as perceived by their teachers. Unpublished Doctoral Dissertation, La Verne, CA: La Verne University.

Csikszentmihalyi, M. (1988). Society, culture, and person: A systems view of creativity. In R. J. Sternberg (Ed.), The nature of creativity: Contemporary psychological perspectives (pp. 325-339). New York: Cambridge University Press.

Dahar, M. A., Faize, F. A., Niwaz, A., Hussain, M. A., \& Zaman, A. (2010). Relationship between the leadership styles and academic achievement at the secondary stage in Punjab. International Journal of Academic Research, 2, 459-462.

Darnell, N., Gallagher, D., Andrews, R., \& Amaral, D. (2000). Environmental management systems: Opportunities for improved environmental and business strategy? Environmental Quality Management, 3, 1-9.

Datnow, A., \& Castellano, M. E. (2001). Managing and guiding school reform: Leadership in success for all schools. Educational Administration Quarterly, 37, 219-249. http://dx.doi.org/10.1177/00131610121969307

Desforges, C. (2000). Classroom learning. The Nineteenth Vernon-Wall Lecture, London: The Education Section of the British Psychological Society.

Desforges, C.W (1995) Learning out of school. In Desforges, C. (Ed.), Introduction to teaching (pp. 5-32). Oxford: Blackwelland.

Desforges, C. W., \& Cockburn, A. D. (1987) Understanding the mathematics teacher: A study of practice in the first school (pp. 167). Lewes: Falmer Press.

Doyle, W. (1977). Learning in the classroom environment: An ecological analysis. Journal of Teacher Education, 28, 51-55. http://dx.doi.org/10.1177/002248717702800616

Doyle, W. (1981). Research on the classroom. Journal of Teacher Education, 32, 3-6.

http://dx.doi.org/10.1177/002248718103200602

Doyle, W. (1983). Academic work. Review of Educational Research, 53, 159-199. http://dx.doi.org/10.3102/00346543053002159

Doyle, W. (1986). Classroom Organization and Management. In M. C. Witttrock (Ed.), Handbook of research on teaching (3rd Edition, pp. 392-431). New York: Macmillan.

Dunford, J., Fawcett, R., \& Bennett, D. (2000). School leadership: National and international perspectives. London: Kogan Sage Limited.

Eisawi, A. R. (1990). Psychology of creativity: A study in the develop- ment of traits of creativity. Beirut: Dar Al-Nahdah Al-Arabiyyah.

Fleith, D. (2000) Teacher and student perceptions of creativity in the classroom environment. Roeper Review, 22, 148-154. http://dx.doi.org/10.1080/02783190009554022

Goertz, M. J. (1991). The relationship of leader effectiveness and selected traits of creativity. Unpublished Doctoral Dissertation, Flagstaff, AZ: Northern Arizona University.

Gunter, H. M. (2001). Leaders and leadership in education. London: Paul Chapman Publishing.

Hersey, P. (2002). Paul Hersey defines situational leadership terms. Journal of Leadership Studies, 8, 8.

Hess, F., \& Kelly, A. (2007) learning to lead: What gets taught in principal-preparation programs. Teachers College Record, 109, 244-274.

Jackson, P. W. (1968). Life in classrooms. New York: Holt, Rinehart, $\&$ Winston.

Jarwan, F. A. R. (1990). Talent, improvement and creativity. www.madinanet.com/alkotob4

Johnson, D. W., \& Johnson, R. T. (1991). Learning together and alone. Englewood Cliffs, NJ: Prentice-Hall.

Koster-Peterson, L. M. (1993). Leadership skills, practices, and behaviors of effective principals in effective schools. Unpublished Doctoral Dissertation, Flagstaff, AZ: Northern Arizona University.

Kouzes, J. M., \& Posner, B. Z. (2003). The leadership challenge. San Francisco, VA: Jossey-Bass.

Lashway, L., Mazarella, J. A., \& Grundy, T. (1996). Portrait of a leader. In S. C. Smith, \& P. K. Piele (Eds.), School Leadership, Handbook for Excellence (pp. 15-38). Eugene, OR: University of Oregon.

Lumsden, L. (1994). Student motivation to learn. ERIC Digest, 92, $43-$ 58 .

http://www.kidsource.com/kidsource/content2/Student_Motivatation. html\#credits

Marchbanks, P. (2000). Personality traits: Elementary school teachersprospective elementary school teachers: Are they out there? http://www.unc.edu/courses/2004spring/engl/012/054/PDF\%20files/ Sample\%20Papers/Unit\%202\%20Project/Unit\%202--teacher.pdf

Mooney, C. G. (2000). Theories of childhood: An introduction to Dewey, Montessori, Erikson, Piaget, \& Vygotsky. St. Paul, MN: Redleaf Press.

Morganett, L. (1991). Good teacher-student relationships: A key element in classroom motivation and management. Education, 112, 260-264.

Morris, R. E. (1998). Principals' leadership practices in the implementtation of site-based management. Unpublished Doctoral Dissertation, West Hartford, CT: University of Hartford.

Muhammad, A. (1996). A comparative analysis of scientific research administrators' leadership practices in public and private universities. Unpublished Doctoral Dissertation, Houston, TX: Texas Southern University.

Munitz, B. (1999). Creative management demands creative leadership. In R. J. Sternberg (Ed.), Handbook of Creativity. New York: Cambridge University Press.

Nolan, F. L. (1992). Ethical leadership and school culture: An exploratory study of nine middle-level schools. Unpublished Doctoral Dissertation, Minneapolis, MN: University of Minnesota.

Oumthanom, P. (2001). Principal leadership bahaviors: Differences in perception. Unpublished Doctoral Dissertation, Normal, IL: Illinois State University.

Plucker, J. A., \& Beghetto, R. A. (2004). Why creativity is domain general, why it looks domain specific, and why the distinction does not matter. In R. J. Sternberg, E. L. Grigorenko, \& J. L. Singer (Eds.), Creativity: From Potential to Realization (pp. 153-167). Washington DC: American Psychological Association. http://dx.doi.org/10.1037/10692-009

Rice, J. K. (2010) The impact of teacher experience examining the evidence and policy implications. Washington DC: CALDER Institute.

Ross, E. W. (2006). The social studies curriculum: Purposes, problems, and possibilities. New York: State University of New York press.

Schmiesing, D. (2001). The effects of leadership skills instruction on leadership practices. Unpublished Masters of Science, Steubenville, 


\section{S. AL-KARASNEH, A. JUBRAN}

OH: University of Steubenville.

Schmook, I. M. L. (1996). Principals' leadership and creativity in selected Florida schools. Ph.D. Thesis, Orlando, FL: University of Central Florida.

Slahova, A., Sawina, J., Cacka, M., \& Volonte, I. (2007). Creative activity in conception of sustainable development education. International Journal of Sustainability in Higher Education, 8, 142-154. http://dx.doi.org/10.1108/14676370710726616

Spiel, C., \& von Korff, C (1998) Implicit theories of creativity: The conceptions of politicians, scientists, artists and school teachers. Journal of High Ability Studies, 9, pp. 43-58.

Starko, A. J. (1995). Creativity and the quest for mechanism. In A. J. Starko, (Ed.), Creativity in the Classroom: Schools of Curious Delight (p. 126). New York: Longman Publishers.

Sternberg, R. J., \& Williams, W. M. (1996). How to develop student creativity.

http://www.ascd.org/ readingroom/books/sternberg96book.html

Stoycheva, K. (1996). The school: A place for children's creativity? Paper presented at the European Council for High Ability Conference, Vienna, Austria.

Sweidan, T. M., \& Adlouni, M. A. (2002). Mabadi' Al-Ibda' [Principles of Creativity]. Kuwait: Sharikat Al-Ibda' Al-Khaliji.

Taylor, T. A. (2002). Examination of leadership practices of principals identified as servant leaders. Unpublished Doctoral Dissertation, Columbia, MO: University of Missouri-Columbia.

Tinzman, M. B., Jones, B. F., Fennimore, T. F., Bakker, J., Fine, C., \&
Pierce, J. (1990). What is the collaborative classroom. North Central Regional Educational Laboratory. http://onlineacademy.org/modules/a402/support/xpages/a402b0_204 00.html

Torrance, E. P., \& Myers, R. E. (1970). Creative learning and teaching. New York: Dodd, Mead, \& Company.

Ubben, G. C., \& Hughes, L. W. (1997). The principal: Creative leadership for effective schools. 3rd Edition. Needham Heights, MA: Allyn and Bacon.

Van Petegem, K., Creemers, B. P. M., Rosseel, Y., \& Aelterman, A. (2005). Relationships between teacher characteristics, interpersonal teacher behaviour and teacher wellbeing. Journal of Classroom Interaction, 40, 34-43.

Weltman, R. (1995). Examine the practice of transformational leadership within National Blue Ribbon Elementary Schools in Cuyahoga County. Unpublished Doctoral Dissertation, Akron, OH: University of Akron.

Wildy, H., \& Louden, W. (2002). School restructuring and the dilemmas of principals' work. Educational Management and Administration, 28, 173-184.

Wilson, E. O. (1992). Sociobiology. Cambridge, MA: Harvard University Press.

$\mathrm{Xu}, \mathrm{Z}$. L. (1991). The relationship between leadership behavior of academic deans in public universities and job satisfaction of department Chairpersons. Unpublished Doctoral Dissertation, Johnson City, TN: East Tennessee State University. 